\title{
F-18 Fluorodeoxyglucose non-avid hepatosplenic $T$ cell lymphoma: a diagnostic pitfall
}

\author{
Siu-Lun Ho • Florence Loong • Clarence Lam • \\ Marina-Portia Anthony • Yok-Lam Kwong
}

Received: 2 May 2011 / Accepted: 9 May 2011 / Published online: 17 May 2011

(C) The Author(s) 2011. This article is published with open access at Springerlink.com

Dear Editor,

A 59-year-old man presented with a 9-month history of transfusion-dependent anaemia, hepatomegaly $(2 \mathrm{~cm})$ and splenomegaly $(6 \mathrm{~cm})$. F-18 fluorodeoxyglucose (FDG) positron emission tomography computed tomography (PET/CT) showed gross hepatosplenomegaly (Fig. 1a) that was eumetabolic (Fig. 1b), raising the possibility that the cause might be non-neoplastic. However, bone marrow examination showed a small population of suspicious $\mathrm{T}$ cells with no clear histopathological patterns. The $\mathrm{T}$ cell receptor (TCR) gamma gene was clonally rearranged on polymerase chain reaction, suggesting that the hepatosplenomegaly might be related to a clonal $\mathrm{T}$ cell neoplasm.

Splenectomy and liver biopsy were performed. Histologically, there was cord expansion and sinusoidal infiltration in the splenic red pulp by small atypical

S.-L. Ho $\cdot$ F. Loong $\cdot$ C. Lam

Department of Pathology, Queen Mary Hospital,

Hong Kong, China

M.-P. Anthony

Department of Diagnostic Radiology, Queen Mary Hospital,

Hong Kong, China

Y.-L. Kwong $(\bowtie)$

Department of Medicine, Professorial Block,

Queen Mary Hospital,

Pokfulam Road,

Hong Kong, China

e-mail: ylkwong@hkucc.hku.hk lymphoid cells (Fig. 1c). These neoplastic lymphoid cells were also found as small aggregates in the hepatic sinusoids (Fig. 1d). On immunophenotyping, the lymphoid cells were CD3+, CD4-, CD8-, TIA-1+, TCR $\beta-$ and $\mathrm{TCR} \gamma+$ (Fig. 1e-h). The overall features were consistent with hepatosplenic T cell lymphoma (HSTCL) of the $\gamma \delta$ subtype.

$\mathrm{PET} / \mathrm{CT}$ is used extensively in the staging and posttreatment follow-up of Hodgkin's lymphoma, where it is considered a standard of care [1]. It is also regarded as highly sensitive in most aggressive and indolent $\mathrm{B}$ cell lymphomas [2]. FDG uptake is usually proportional to histopathological grading, being very avid in high-grade lymphomas that are metabolically active. Although this pattern is generally observed in B cell lymphomas, it is undefined if FDG uptake also parallels the clinical behaviour in $\mathrm{T}$ cell lymphomas. In fact, PET/CT has been reported to be negative in some $\mathrm{T}$ cell malignancies, notably T-large granular lymphocyte leukaemia and T-prolymphocytic leukaemia [3]. HSTCL is an aggressive lymphoma with a poor survival. It accounts for less than $1 \%$ of all lymphomas. Because HSTCL is rare, the application of PET/CT in its diagnosis and management has not been evaluated. FDG avidity had only been previously reported in a single case of HSTCL occurring after liver transplantation [4]. Our case apparently had arisen de novo. The lymphoma was entirely FDG nonavid, constituting a diagnostic pitfall. Therefore, the role of PET/CT in the diagnosis and follow-up of $\mathrm{T}$ cell lymphomas may have to be carefully defined for each histopathological type [5]. 


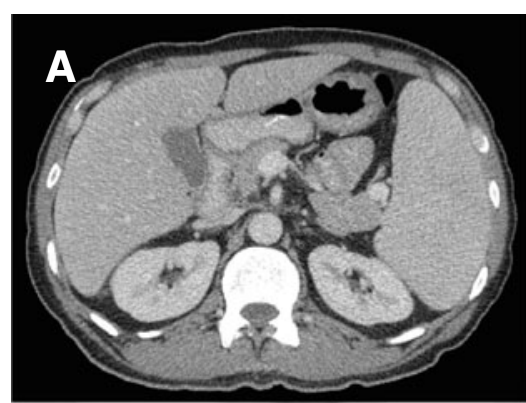

B

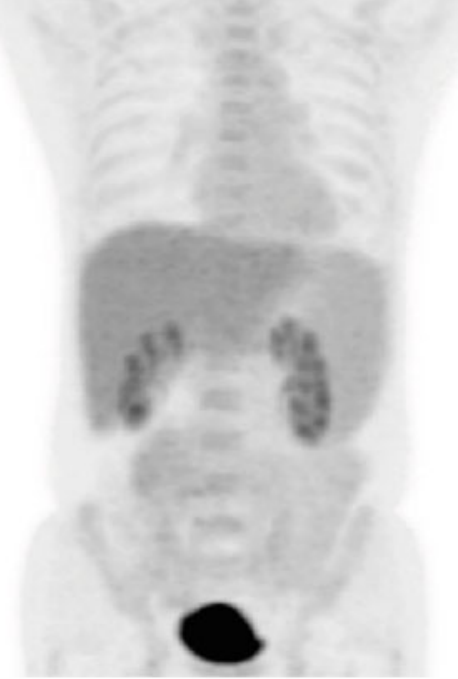

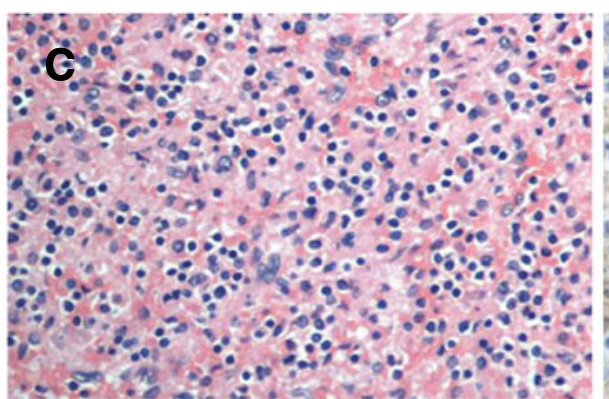
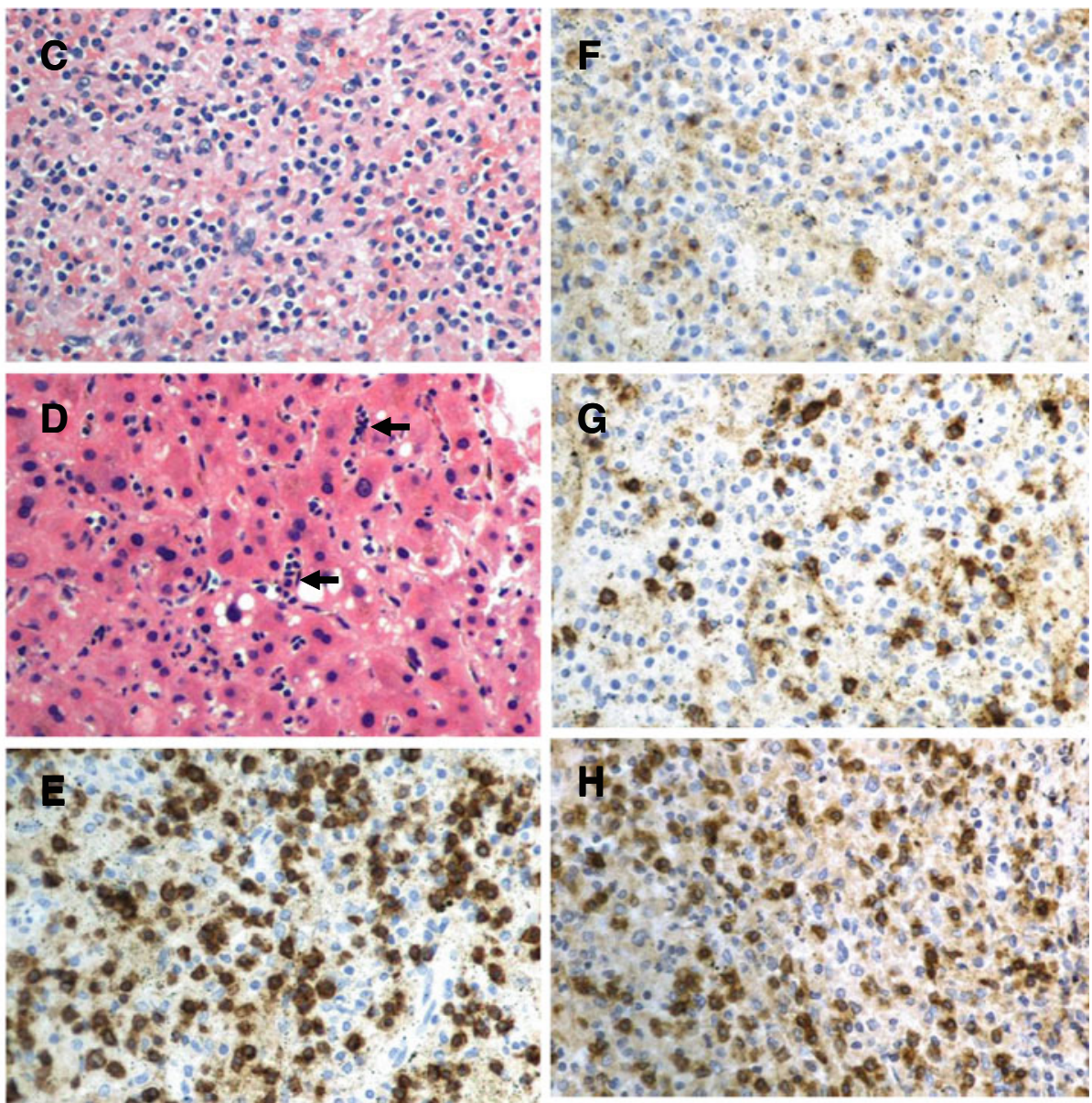

Fig. 1 A case of hepatosplenic $\mathrm{T}$ cell lymphoma with negative positron emission tomography. a Computed tomography of the abdomen, showing gross hepatosplenomegaly. b Positron emission tomography showing that the hepatosplenomegaly was eumetabolic. c The spleen showed red pulp infiltration by atypical lymphoid cells. $\mathbf{d}$
The liver showed infiltration of sinusoids (arrows) by atypical lymphoid cells. e-h Immunoperoxidase staining, showing that the lymphoma cells were positive for CD3 (e), negative for CD4 and CD8 (f, g), and positive for TCR $\gamma(\mathbf{h})$
Open Access This article is distributed under the terms of the Creative Commons Attribution Noncommercial License which permits any noncommercial use, distribution, and reproduction in any medium, provided the original author(s) and source are credited.

\section{References}

1. Gallamini A, Hutchings M, Rigacci L, Specht L, Merli F, Hansen M, Patti C, Loft A, Di Raimondo F, D'Amore F, Biggi A, Vitolo U, Stelitano C, Sancetta R, Trentin L, Luminari S, Iannitto E, Viviani S, Pierri I, Levis A (2007) Early interim 2-[18F]fluoro-2-deoxy-Dglucose positron emission tomography is prognostically superior to international prognostic score in advanced-stage Hodgkin's lymphoma: a report from a joint Italian-Danish study. J Clin Oncol $25: 3746-3752$
2. Juweid ME, Stroobants S, Hoekstra OS, Mottaghy FM, Dietlein M, Guermazi A, Wiseman GA, Kostakoglu L, Scheidhauer K, Buck A, Naumann R, Spaepen K, Hicks RJ, Weber WA, Reske SN, Schwaiger M, Schwartz LH, Zijlstra JM, Siegel BA (2007) Imaging Subcommittee of International Harmonization Project in Lymphoma. Use of positron emission tomography for response assessment of lymphoma: consensus of the Imaging Subcommittee of International Harmonization Project in Lymphoma. J Clin Oncol 25:571-578

3. Khong PL, Pang CB, Liang R, Kwong YL, Au WY (2008) Fluorine18 fluorodeoxyglucose positron emission tomography in mature T-cell and natural killer cell malignancies. Ann Hematol 87:613-621

4. Roelandt PR, Maertens J, Vandenberghe P, Verslype C, Roskams T, Aerts R, Nevens F, Dierickx D (2009) Hepatosplenic gammadelta T-cell lymphoma after liver transplantation: report of the first 2 cases and review of the literature. Liver Transpl 15:686-692

5. Cheson BD (2011) Role of functional imaging in the management of lymphoma. J Clin Oncol 29:1844-1854 